\title{
Intensity, Profitability and Disclosure of Biological Assets of Agricultural Companies
}

\author{
Nikmah $^{1}$, Muhammad Taufik², Fitrawati Ilyas ${ }^{3}$ \\ Fakultas Ekonomi dan Bisnis, Universitas Bengkulu, INDONESIA ${ }^{1,2,3}$
}

\begin{tabular}{l}
\hline \hline ARTICLE INFO \\
\hline \hline Article history: \\
Received: Nov 11,2021 \\
Revised: Feb 15, 2022 \\
Accepted: Feb 25, 2022 \\
\hline Keywords: \\
Intensity of biological assets; \\
Profitability; Disclosure of \\
biological assets \\
\hline
\end{tabular}

\begin{tabular}{l}
\hline Correspondence: \\
Nikmah \\
nikmahbmb@gmail.com
\end{tabular}

\begin{tabular}{l}
\hline \hline ABSTRACT \\
The agricultural sector is a sector that plays an important role ini the \\
Indonesian economy because Indonesia is an agriculture country. In \\
agriculture companies, biological asset are part of the company's assets. This \\
study examines the effect of biological asset intensity and profitability on the \\
disclosure of biological assets of agriculture companies. This study was tested \\
using multiple regression analysis. The sample used in this study is \\
agricultural companies listed on the Indonesia Stock Exchange in 2018-2020. \\
The data in this study is obtained from secondary source i.e. www.idx.com. \\
The results of this study show the intensity of biological assets has a positive \\
effect on the disclosure of biological assets and profitability does not have a \\
positive effect on the disclosure of biological assets.
\end{tabular}

How to cite (APA Style):

Nikmah, Taufik, M., Ilyas, F. (2022). Intensity, Profitability and Disclosure of Biological Assets of Agricultural Companies.

Jurnal Akuntansi, 12 (1), 51-62. https://doi.org/10.33369/j.akuntansi.12.1.51-62

\section{INTRODUCTION}

Indonesia is a country with a lot of wealth and natural resources, therefore natural wealth is one of the main drivers of the Indonesian economy. Because the majority of the population work in agricultural sector, Indonesia is known as an agricultural country. Being an agricultural country, the agricultural sector is strategically important to improve the living standards of the Indonesian population through the production of food, fiber and other products. Plantations, agriculture, fisheries, cattle, and forestry are all examples of natural resources in the agricultural sector, which are together referred to as biological assets. A biological asset according to Statement of Financial Accounting Standard No. 69 is an asset (animal or living plant) that can produce agricultural products, can become agricultural products, or can even produce other biological assets as products. The uniqueness of assets from this sector is that biological assets can be transformed within a certain period of time (Sakinatunnisak \& Budiwinarto, 2020), the biological transformation of live agricultural and plantation crops and livestock can yield a product that can later be consumed or processed further. The biological asset transformation in agricultural companies according to Sharlica (2017) consists of growth, degeneration, production and procreation and this requires a measurement that can show the asset value fairly in accordance with its contribution in generating profits for that company. Disclosure of the value of biological assets in companies is carried out through information submitted in financial reports and annual reports (Sa'diyah, et al 2019). The practice of disclosing biological assets by agricultural companies in Indonesia prior to PSAK 69 was still small and did not reflect the true value of biological assets. However, after the enactment of PSAK 69 on January 1, 2018, issuers with agricultural activities changed their accounting treatment in order to measure the biological assets and agricultural products harvested at fair value were disclosed. Disclosure of the value of biological assets in detail can help potential investors or other stakeholders in making decisions. This is a relatively a new issue in accounting and the lack of references to the disclosure of biological assets motivates researchers to re-examine the factors that can affect the disclosure of biological assets of agricultural companies, one of which is the intensity of biological assets and profitability. The 
intensity of biological assets shows the amount of investment value contained in biological assets while profitability indicates the ability of agricultural companies to obtain a certain level of profit through biological assets.

Previous research has provided inconsistent empirical evidence regarding the relationship between the intensity of biological assets and profitability on the disclosure of biological assets. Research by Gonçalves \& Lopes (2014), Amelia (2017), Duwu, Daat, \& Andriati (2018), Putri \& Siregar (2019), Arissandi, Setiawan, \& Wiludjeng (2019), Hayati \& Serly (2020) and Sakinatunnisak \& Budiwinarto (2020) prove that the intensity of biological assets positively affects the disclosure of biological assets. Different results are shown by Sa'diyah et al., (2019) proving that the intensity of biological assets has a negatively affect on the disclosure of biological assets, and the results of research by Aliffatun \& Sa, (2020) and Zufriya, et al., (2020) have results of intensity biological assets does not affect the disclosure of biological assets. Empirical testing for the effect of profitability on disclosure of biological assets also provides mixed empirical evidence. Research by Sakinatunnisak \& Budiwinarto (2020), Gustria and Sabrina (2020), Riski, et al., (2019) proves that profitability has a positive effect. However, the results of Duwu et al., (2018) and Zufriya et al., (2020) research show that profitability does not affect the disclosure of biological assets.

The inconsistency of previous researches motivates researchers to re-examine the relationship between the intensity of biological assets and profitability on the disclosure of biological assets. The problem raised in this study is whether there is an effect of the intensity of biological assets and profitability on the disclosure of biological assets. The purpose of this study is to determine whether the level of disclosure of biological assets is influenced by the intensity of biological assets profitability.

\section{Signaling Theory}

Signaling theory states that the information conveyed by the owner of the information is a signal or cue for the recipient of the information (Spence, 1973). When a company discloses information about the company, the company actually wants to give a positive signal to investors about the company's performance. Disclosure of the intensity of biological assets and profitability by agricultural companies are a positive signal from the company to attract investors to invest in the company. Thus, the more disclosures that investors receive, the more information will be obtained so that investors will be more confident to invest in the company

\section{Stakeholder theory}

According to stakeholder theory, companies operate not only for their own interests but have an obligation to pay attention to their stakeholders. Management must have good relationships with the stakeholders because they are all parties, both internal and external, who have an interest in the company. Stakeholders include shareholders, investors, creditors, government, customers, company employees, and the general public. Disclosure made by management is one strategy to maintain relationships with stakeholders which can be done by providing information on the company's performance in terms of economic, social, and environmental aspects. Through the disclosure of biological assets by agricultural companies, it is expected to meet the information needed by stakeholders for the sustainability of the company. The existence of support from stakeholders will be able to increase the value of the company.

\section{Biological assets}

Biological assets are one of the assets of agricultural activities. According to PSAK No. 69 (IAI, 2018), biological assets are defined as assets in the form of living animals or plants. Biological assets in the financial statements can be recognized as current assets or non-current 
assets according to the period of biological transformation of the biological assets concerned. Companies that have agricultural activities must measure biological assets and harvested agricultural products at fair value. Measurement of the fair value of biological assets or agricultural products is done by grouping them according to age or quality, or other attributes. The basis for determining attributes follows the market as the basis for determining prices. Fair value should reflect current market conditions in which the seller and buyer transact. In certain circumstances, the cost of a biological asset sometimes approximates the estimated fair value; for example, seedlings planted or newly acquired livestock close to the reporting end date. This is because the biological transformation process starting from growth, degeneration, production, and procreation that changes the quality and quantity of biological assets has not materially taken place. The fair value of biological as sets can also be measured using combined or single asset information for physically attached biological assets, such as biological assets attached to land such as trees in a forest. If there is an active market for the combined assets, the fair value of the biological assets can be measured after the fair value of the combined assets is reduced by the fair value of the land and land development.

\section{Biological Asset Disclosure \& Intensity}

Disclosure is a way of company communication related to economic information carried out by entities in terms of financial information and non-financial information related to the company, as well as quantitative information or other information that shows the company's performance (Owusu-Ansah, 1998). Disclosure of biological assets in PSAK 69 Agriculture is the disclosure of quantitative descriptions of biological assets which are divided into groups of biological assets that can be consumed and productive biological assets (bearer biological assets), or between mature and immature biological assets. This distinction provides useful information for assessing the timing of future cash flows. The entity must also disclose the basis for making that distinction.

Asset Intensity is an illustration of how much investment is made by the company in assets or the proportion of investment by agricultural companies to its biological assets (Duwu, 2018 and Amelia Frida, 2017) or in other words, the intensity of biological assets is information that shows how much the company's investment in biological assets in the company. If the biological assets owned by large companies that make disclosures, then the disclosure of information related to the intensity of biological assets in the financial statements provides confirmation that companies comply with regulations and compliant companies tend to get more attention from stakeholders.

\section{Profitability}

Profitability is the ability of an entity to generate a profit and support growth in both shortterm as well as long-term. Profitability can be measured in several ways as given below:

1. Return on equity (ROE) is a ratio to measure net profit after tax with own capital. A high ROE indicates the company's management has a good ability to manage available equity to maximize net income available to shareholders. The higher this ratio, the higher the probability that dividends will be distributed or reinvested as retained earnings.

2. Net profit margin (NPM) is a profitability ratio to assess the percentage of net profit obtained from sales after deducting taxes. This net profit margin is also known as the profit margin ratio. The higher the net profit margin, the more profitable a company is.

3. Return on assets (ROA) is a ratio to measure how much the rate of return on assets. This ratio reflects how effectively the company uses its assets. The higher this ratio, the more effective the use of these assets. This study uses the ROA profitability ratio by using net income after tax as a divisor from total assets. Return on Assets is used in measuring 
profitability in this study because it is able to show the company's profitability and the company's effectiveness in managing its assets.

\section{Biological Asset Intensity and Biological Asset Disclosure}

Based on the signal theory, the management tries to provide a positive signal in the form of relevant information that can be used by investors to make decisions based on an understanding of the information provided by the management. When a company has a high level of biological asset intensity and discloses it, the company tries to give a signal to attract investors to invest their capital in the company. Companies will tend to make more disclosures, because the more disclosures received by investors, the more information will be obtained so that investors will be more confident to invest their capital in the company. This is also supported by stakeholder theory which states that companies are not entities that only operate for their own interests but must provide benefits to stakeholders (Ghozali \& Chariri, 2007). To get support from stakeholders, the company's management will provide actual information, one of which is information about the intensity of biological assets. Disclosure of information regarding the intensity of biological assets is conveyed by management to make it easier for stakeholders to know how big the company's investment proportion is on biological assets owned by the company. Research by Gonçalves \& Lopes (2014) and Putri \& Siregar (2019) proves that there is a positive relationship between the intensity of biological assets and the disclosure of biological assets. The positive effect on the disclosure of biological assets means that the greater the intensity of biological assets, the company will tend to disclose their biological assets. This opinion is in line with Silva, et al (2012) which states that according to stakeholder theory, management provides financial reports on biological assets in accordance with IAS 41 to provide information to users of financial statements. Amelia's research (2017) also reinforces this, which shows that companies disclose the intensity of biological assets in the notes to financial statements. Based on the description above, the first hypothesis in this study is:

$\mathrm{H}_{1}$ : Intensity of Biological Assets has a positive effect on Disclosure of Biological Assets

\section{Profitability and Disclosure of Biological Assets}

Kasmir (2012) states that profitability is a ratio that shows of the level of effectiveness of the use of company resources by company management as indicated by the amount of profit generated from company activities (Kasmir, 2012). Profitability also reflects how well the company is performing. Based on signal theory, profitability information is a positive signal that will be conveyed by the company management to its investors. Companies with high profitability will be encouraged to convey this information to outsiders as a signal that the company has good performance. Widiastuti's research (2004) proves that companies with high profit margins tend to provide more detailed information, because most investors are more interested in companies that have a high level of profitability, because of the expectation that companies with high profitability can provide a high rate of return. Companies that do not have high profits will make disclosures only so that the company follows the provisions of the regulations that have been set (Hackston and Milne 1996). This is also in line with research (Riski et al., 2019) which shows that profitability has an effect on the disclosure of biological assets. From the explanation above, the second hypothesis in this study is:

$\mathrm{H}_{2}$ : Profitability positively affects the disclosure of biological assets.

\section{RESEARCH METHODS}

This study is a quantitative research that aims to know the effect of the intensity of biological assets and rea on the disclosure of biological assets aimed at agricultural companies listed on the Indonesia Stock Exchange. The population in this study were used all agricultural 
companies listed on the Indonesia Stock Exchange. The method of determining the sample used in this study by setting the sample criteria as follows: (1) Agricultural companies listed on the Indonesia Stock Exchange from 2018-2020; (2) Agricultural companies that publish annual reports from 2018-2020 and are available on the website and can be accessed and (3) Agricultural companies have biological assets during 2018-2020. This study uses secondary data in the form of annual reports of agricultural sector companies listed on the Indonesia Stock Exchange in the 2018-2020 period which are sourced from www.idx.co.id and each company's website. The method of data collection in this research is the documentation method.

\section{Operational Definition dan Measurement of Variables}

The variables used in this study consisted of independent variables and dependent variables. The independent variables in this study are Intensity of Biological Assets (IAB) and Profitability (ROA). Dependent variable is the disclosure of biological assets (PAB).

1) Intensity of Biological Assets (IAB), that is the proportion of investment by agricultural companies on their biological assets. Measurements for biological asset intensity are as follows (Duwu, 2018):

$$
\mathrm{IAB}=(\text { Total Value of Biological Assets }) / \text { (Total Assets })
$$

2) Profitability, reflects the level of effectiveness of the use of assets by agricultural companies which is indicated by the profit generated from the company's activities. Measurement of profitability using the ratio of Return on Assets (ROA) are as follow (Kasmir, 2012):

$\mathrm{ROA}=($ Net profit after tax $) /($ Total Assets $)$

3) Disclosure of biological assets (PAB) is a descriptive disclosure of biological assets owned by the agriculture companies. PAB is measured using a disclosure index that describes the number of biological asset items and biological asset policies owned and disclosed by the agriculture company from a total of 36 disclosure items. The higher the biological asset disclosure index, the more biological asset items the company discloses. The biological asset disclosure index is calculated using the formula:

$\mathrm{PAB}=($ number of items disclosed $) / 36$

\section{Analysis method}

Descriptive statistics

Descriptive statistics is to provide an overview of research data that can be seen from the average value (mean), standard deviation, variance, maximum, and minimum (Ghozali, 2016). Descriptive statistical analysis in this study is used to provide an overview of asset intensity variables, profitability and disclosure of biological assets.

\section{Classic assumption test}

Classical assumption test that must be met so that the conclusions from the test results are not biased. Classical assumption test includes normality test, heteroscedasticity test, multicollinearity test and autocorrelation test (Ghozali, 2016), there are Normality Test, Heteroscedasticity test multicollinearity test and autocorrelation test. Normality Test aims to see the distribution of the collected data is normally distributed or not, where the decision to accept or reject the hypothesis is made by comparing the probability value with the level of significance. Heteroscedasticity test aims to ensure that in the regression model there is no variance inequality from the residuals of one observation to another. To detect the occurrence of heteroscedasticity, the Glejser test was carried out by regressing the absolute value of the residual to the independent variable, provided that if the correlation coefficient of all variables to the residual $>0.05$, it can be concluded that the regression model does not occur 
heteroscedasticity. Multicollinearity test, aims to ensure that in the regression model there is no correlation between independent variables (independent). If the independent variables are correlated with each other, then these variables are not orthogonal. Autocorrelation test, aims to ensure that in the regression model there is no correlation between the nuisance error in period $t$ and the error in period $t-1$.

\section{Model Feasibility Test}

The feasibility test of the model aims to test whether the regression function is appropriate in measuring the actual statistical unit of value. The feasibility test of the model uses the F Statistical Test which shows a match between the data and the research model. The basis for decision making for the F statistical test is the significance value 0.05 , then the regression model is feasible (fit) and Significance value > 0.05, then the regression model is not feasible.

\section{Coefficient of Determination Test (R2)}

The Coefficient of Determination Test aims to measure how much the independent variable's ability to explain the variation of the dependent variable is. The value of the coefficient of determination is between zero and one. The smaller R2 value indicates the lower the level of ability of the independent variables in explaining the dependent variable. On the other hand, the level of ability of the independent variable in explaining the dependent variable is higher if the value of $\mathrm{R} 2$ is greater.

\section{Hypothesis test}

1) Multiple Regression AnalysisMultiple regression analysis in this study was used to examine the effect of the independent variables which include the intensity of biological assets and profitability on the dependent variable, namely the disclosure of biological assets, while the regression equation model in this study is as follows:

$$
\left.\mathrm{PAB}=\alpha+\beta_{1} \mathrm{IAB}+\beta_{2} \mathrm{ROA}+\mathrm{e} \quad \ldots \ldots \ldots 4\right)
$$

Where:

$$
\begin{aligned}
& \mathrm{PAB}=\text { Disclosure of Biological Assets } \\
& \mathrm{IABI}=\text { Intensity of Biological Assets } \\
& \text { ROA }=\text { Profitability } \\
& \beta_{1}, \beta_{2}=\text { regression coefficient } \\
& \mathrm{e}=\text { error }
\end{aligned}
$$

2) Individual Parameter Significance Test (Test statistic t )

The $t$ statistical test was used to test the significant level of the influence of the independent variables individually on the dependent variable (Ghozali, 2016). This test is done by looking at the significance value of $t$ for each variable. If the significance value of $t 0.05$ with $\beta>0$ then the hypothesis is accepted. On the other hand, if the significance value of $t$ 0.05 and $\beta<0$ then the hypothesis is rejected.

\section{RESULT AND DISCUSSION}

\section{Description of Research Data}

Descriptive statistics provide an overview of the variables of profitability and intensity of biological assets as well as disclosure of biological assets. The results of descriptive statistics in this study are presented in table below: 
Table 1. Descriptive statistics

\begin{tabular}{lccccc}
\hline Variable & $\mathrm{N}$ & Minimum & Maximum & Mean & Std. Deviation \\
\hline $\begin{array}{l}\text { Disclosure of } \\
\text { biological assets }\end{array}$ & 45 & 0.58333 & 0.88889 & 0.784567 & 0.0803670 \\
$\begin{array}{l}\text { (PAB) } \\
\text { Profitability (ROA) }\end{array}$ & 45 & -0.51746 & 0.14606 & 0.008588 & 0.0913239 \\
$\begin{array}{l}\text { Biological asset } \\
\text { intensity (IAB) }\end{array}$ & 45 & 0.00173 & 0.12195 & 0.013516 & 0.0179229 \\
\hline
\end{tabular}

Source: Processed Data, 2021

Based on the specified sample criteria, as many as 45 agricultural companies that met the criteria. The statistical results of the use of biological assets which are measured by samples using 36 indicators based on PSAK 69 for 45 samples get the results of a biological asset index with a minimum value of 0.58333 , this means that from the findings of companies that disclose their biological assets at least only 0.58333 or only $58.3 \%$ of the total items regulated in PSAK 69. The maximum value of 0.889 indicates that there are agricultural companies that have reported disclosure of biological assets of 0.88889 or $89 \%$ of the total 36 disclosure items. On average, the sample companies have disclosed biological assets of 0.784567 or $78.45 \%$ of the 36 total disclosure items with a standard deviation of 0.080367 . The average value of 0.784567 shows that the majority of the companies that are the research sample have made disclosures of biological assets in accordance with PSAK 69 above 50\%, this shows the average research sample, namely agricultural companies have followed the regulations issued through PSAK 69. On average, agricultural companies have provided mandatory and voluntary disclosures of biological assets. The value of the standard deviation of the disclosure of biological assets itself is 0.080367 and is smaller than the average value (mean) of 0.784567 , meaning that the value of disclosure of biological assets in all observations does not vary.

For the profitability variable (PFB) as measured by ROA, it shows descriptive statistical results, namely the minimum value of -0.51746 which indicates that in the research sample during the 2018-2020 period, there are agricultural companies that experience losses. The highest profitability that can be achieved by the sample companies is only 0.14606 or $14.6 \%$, while the average profitability of the sample companies is 0.0085883 by $0.8 \%$. These results illustrate that in the research period the company's profitability is still relatively low. The average sample company has not been maximal in utilizing assets to increase profits.

Descriptive statistics for the biological asset intensity variable (BAI) show that on average the sample companies have a proportion of biological assets of 0.0135162 or $1.3 \%$ of the total assets owned by the company. The highest proportion of biological assets in the sample companies is 0.12195 or $12.19 \%$ and the lowest is 0.00173 or $0.17 \%$ of the total assets. This reflects that the proportion of biological assets is still a small part of the assets of agricultural companies

\section{Classic Assumption Test Results}

The following are the results of classical assumption test carried out in this research model.

Table 2. Normality Test Results

\begin{tabular}{|c|c|c|c|c|}
\hline Variable & $\Lambda$ & $\begin{array}{l}\text { Kolmogorov- } \\
\text { smirnov }\end{array}$ & Asymp. Sig (2-tailed) & Result \\
\hline $\begin{array}{c}\text { Unstandardized } \\
\text { Residual }\end{array}$ & $\begin{array}{l}4 \\
5\end{array}$ & 0.975 & 0.298 & Normalize Data \\
\hline
\end{tabular}


Intensity, Profitability and Disclosure of Biological Assets of Agricultural Companies Nikmah, Muhammad Taufik, and Fitrawati Ilyas

Table 3. Heteroscedasticity Test Results Coefficients ${ }^{\mathrm{a}}$

\begin{tabular}{ccc}
\hline Variable & Sig & Result \\
\hline IAB & 0.380 & Heteroscedasticity Free \\
ROA & 0.085 & Heteroscedasticity Free
\end{tabular}

Table 4. Multicollinearity Test Results Coefficients ${ }^{\mathrm{a}}$

\begin{tabular}{cccc} 
Variable & \multicolumn{2}{c}{ Collinearity Statistics } & Remark \\
\cline { 2 - 3 } & Tolerance & VIF & \\
\hline IAB & 0.792 & 1.263 & Multicollinearity free \\
ROA & 0.792 & 1.263 & Multicollinearity free \\
\hline
\end{tabular}

Table 5. Autocorrelation Test Results Model Summary ${ }^{b}$

\begin{tabular}{cccccccc}
\hline $\mathrm{K}$ & $\mathrm{N}$ & $\mathrm{Dl}$ & $\mathrm{Du}$ & $\mathrm{Dw}$ & $4-\mathrm{Du}$ & Criteria & Remark \\
\hline 2 & 45 & 1.47538 & 1.56602 & 1.651 & 2.43398 & $\mathrm{Du}<\mathrm{Dw}<4-\mathrm{Du}$ & $\begin{array}{l}\text { There is no negative and } \\
\text { positive autocorrelation }\end{array}$ \\
\hline
\end{tabular}

\section{Hypothesis Test Results}

Based on the hypothesis testing conducted, the test results are obtained as follows:

Table 6. Hypothesis Testing Results Coefficients ${ }^{\mathrm{a}}$

\begin{tabular}{cccc}
\hline Variable & Coefficient & $\mathrm{t}$ & Sig \\
\hline IAB & 0.884 & 2.278 & 0.028 \\
ROA & -0.276 & -3.799 & 0.000 \\
\hline
\end{tabular}

Source: Processed secondary data, 2021

\section{The Influence of Biological Asset Intensity on Biological Asset Disclosure}

The intensity of biological assets is the information presented by the company to show the company's investment in biological assets in the company, while the disclosure of biological assets provides an overview of what companies have disclosed regarding biological assets owned by the company based on PSAK 69 in the financial statements. Based on the results of testing hypothesis 1 , it shows that the biological asset intensity variable has a positive effect on the disclosure of biological assets, it means that companies that have a large biological asset intensity will show a more intensive level of biological asset disclosure, meaning that the greater the biological asset value, the higher the company provides complete and detailed information about biological assets to users of financial statements. The disclosure is a signal to give confidence to investors that the biological assets owned by the company can be managed by the company and are a source of profit for companies in the agricultural sector and as a form of accountability to stakeholders. The results of this study can prove the signal theory which explains that management tries to provide relevant information that can be used by investors, so that investors can make decisions that come from understanding the information provided by management and stakeholder theory which states that to get support from the stakeholders of the company's management will report the proportion of the intensity of the biological assets owned by the company and this is conveyed as a form of management responsibility as the manager of the company who should report all information and reports regarding the management of the company to stakeholders. The disclosure of biological assets 
by the company also illustrates that the company has followed the provisions of PSAK 69 which regulates the disclosure of biological assets. The results of this study are in line with research by Amelia (2017), Gonçalves \& Lopes (2014) and Putri \& Siregar (2019) which show that the intensity of biological assets has a positive effect on disclosure of biological assets.

\section{The Effect of Profitability on Disclosure of Biological Assets}

Profitability is one of the factors that become the center of attention to investors, because companies with high profitability reflect that the company has large financial resources and has good growth prospects in the future, thus encouraging them to disclose information other than those required. A high level of profitability indicates that the company's ability to manage the company to generate profits is also high, high profitability will be in demand by investors so that it can be used as a reference for companies to make disclosures. Based on the Signaling theory, it can be explained that by disclosing the profitability obtained by the company, the company is in the form of giving a positive signal in the form of information about good company performance in generating profits, thus the higher the profitability, the more disclosures will be conveyed so that the greater the confidence of investors in investing their capital which will also increase the company's profitability.

Based on the results of testing, the effect of profitability on the disclosure of biological assets, it shows that the profitability variable has a negative effect on the disclosure of biological assets. The results of this study are not in line with the signaling theory which explains that the higher the profitability, the more disclosures will be conveyed. Companies with high profitability will be encouraged to convey information signals to outsiders that the company has good performance, but based on the test results show that agricultural companies that have high profitability tend to reduce the disclosure of their biological assets, this is because agricultural companies that become The sample in this study is classified as low and some suffer losses. This reflects that the condition of the performance of the agricultural companies that are the research sample has not met expectations so that they are considered unprofitable, so that agricultural companies do not prioritize the disclosure of biological assets for the purpose of obtaining new potential investors. This result is also strengthened by the condition of investment in biological assets to total assets in agricultural companies which are still relatively small.

The results of this study also cannot fully confirm the stakeholder theory which states that disclosure is a strategy to maintain relationships with stakeholders which can be done by providing information on company performance. However, the results of this study are in line with the research conducted by Riski (2019) which proves that companies with high levels of profitability will tend to make smaller efforts in disclosing information when compared to companies that have low levels of profitability but are not in line with the results of Pramitasari's research (2018). Kamijaya (2019), and Abrar (2019) who concluded that the profitability of an agricultural company has no effect on the disclosure of the company's biological assets.

\section{CONCLUSION AND SUGESTION}

Based on the results of testing to prove that the intensity of biological assets positively affects the disclosure of biological assets of agricultural companies, this indicates that an increase in the intensity of biological assets the company is followed by an increase in the disclosure of biological assets. Profitability does not affect positively on the disclosure of biological assets. agricultural companies disclose their biological assets in accordance with the provisions stipulated in PSAK 69 both when the profitability of the company owned is low or high. 


\section{REFERENCES}

Abdullah, Achmad Ridwan. (2011). "Perlakuan Akuntansi Aset Biologis Pt.Perkebunan Nusantara Xiv Makassar (Persero)”. Skripsi. Makassar: Fakultas Ekonomi, Universitas Hasanuddin.

Adisamartha, I.B. \& Noviari, N. (2015). Pengaruh Likuiditas, Leverage, Intensitas Persediaan Dan Intensitas Aset Tetap Pada Tingkat Agresivitas Pajak Wajib Pajak Badan. E-Jurnal Akuntansi. $13(3)$ 973-1000. https://ojs.unud.ac.id/index.php/Akuntansi/article/view/14496

Alfiani, L. K., \& Rahmawati, E. (2019). Pengaruh Biological Asset Intensity , Ukuran Perusahaan, Manajerial, dan Jenis KAP Terhadap Pengungkpan Aset Biologis ( Pada Perusahaan Agrikultur yang Terdaftar di Bursa Efek Indonesia Periode 2014-2017). Reviu Akuntansi Dan Bisnis Indonesia, 3(2), 163-178.

Aliffatun, A., \& Saadah, L. (2020). Pengaruh Intensitas Aset Biologis , Ukuran Perusahaan dan Konsentrasi Kepemilikan Manajerial terhadap Pengungkapan Aset. Journal of Islamic Accounting and Tax, 3(1), 1-8.

Amelia, F. (2017). Pengaruh Biological Asset Intensity, Ukuran Perusahaan, Konsentrasi Kepemilikan, Dan Jenis Kap Terhadap Pengungkapan Aset Biologis. Tesis Universitas Andalas

Amelia, F. (2018). Effect of Biological Asset Intensity , Company Size , Ownership Concentration, and Type Firm against Biological Assets Disclosure. The Indonesian Journal of Accounting Research, 21(1), 121-146. https://doi.org/10.33312/ijar.338

Arissandi, D., Setiawan, christina T., \& Wiludjeng, R. (2019). Pengungkapan Aset Biologis Pada Perusahaan Agrikultur di Indonesia serta Faktor yang Mempengaruhinya. Jurnal Borneo Cendekia, 3(2), 40-46.

Brigham, Eugene F dan Houston. 2006. Fundamental of Financial Management: Dasar-Dasar ManajemenKeuangan. Edisi 10. Jakarta: SalembaEmpat.

Duwu, M. I., Daat, S. C., \& Andriati, H. N. (2018). Pengaruh Biological Asset Intensity, Ukuran Perusahaan, Konsentrasi Kepemilikan, Jenis KAP, dan Profitabilitas Terhadap Biological Asset Disclosure. Jurnal Akuntansi Dan Keuangan Daerah, 13(November), $56-75$.

Freeman, R. E. (1984). Strategic management: A stakeholder approach. Boston: Pitman.

Ghozali, I. (2016). Aplikasi Analisis Multivariate Lanjutan dengan Program SPSS. Semarang: Badan PenerbitanUniversitasDiponogoro.

Ghozali, I. \& Chariri, A. (2007). Teori Akuntansi. Badan Penerbit Universitas Diponegoro, Semarang.

Gonçalves, R., \& Lopes, P. (2014). Firm-specific Determinants of Agricultural Financial Reporting. Procedia - Social and Behavioral Sciences, 110, 470-481. https://doi.org/10.1016/j.sbspro.2013.12.891

Handoko. (2013). Manajemen, ed. Kedua, Cetakan Ketiga belas, BPFE, Yogyakarta.

Handoko, T. Hani. (2014). Manajemen Personalia dan Sumber Daya Manusia. BPFE, Yogyakarta

Hayati, K., \& Serly, V. (2020). Pengaruh Biological Asset Intensity, Growth, Leverage, dan 
Tingkat Internasionalisasi Terhadap Pengungkapan Aset Biologis. Jurnal Eksplorasi Akuntansi, 2(2), 2638-2658.

IkatanAkuntan Indonesia, 2018, StandarAkuntansiKeuangan, Jakarta: IAI.

Kasmir. (2012). Analisis Laporan Keuangan. Jakarta : Pt Raja Grafindo Persada

Kusumadewi, A. A. (2018). Pengaruh Biological Asset Intensity dan Ukuran Perusahaan terhadap Pengungkapan AsetBiologis (Pada Perusahaan Perkebunan yang Terdaftar di BEI Periode 2017). Skripsi. UniversitasPasundan.

Kamijaya, Mulyadi. (2019). Pengaruh Ukuran Perusahaan, Kosentrasi Kepemilikan, Dan Profitabilitas Terhadap Pengungkapan Aset Biologis Pada Perusahaan Agrikultur.Skripsi Universitas Katolik Widya Mandala.

Lusy, Widiastuti. (2004). Faktor-Faktor Yang Mempengaruhi Kelengkapan Pengungkapan Laporan Keuangan Pada Perusahaan Manufaktur Yang Terdaftar Di Bursa Efek jakarta.

Owusu-Ansah, S. (1998). The Impact Of Corporate Attributes On The Extent Of Mandatory Disclosure And Reporting By Listing Companies In Zimbabwe. International Journal Of Accounting. 33(5), 605-631

Riski, T., Probowulan, D., \& Murwanti, R. (2019). Dampak Ukuran Perusahaan, Konsentrasi Kepemilikan Dan Profitabilitas Terhadap Pengungkapan Aset Biologis. Jurnal Ilmu Sosial Dan Humaniora, 8(1), 60. https://doi.org/10.23887/jish-undiksha.v8i1.21355

Ross, S. A. (1977). Determination of Financial Structure: the Incentive-Signalling Approach. Bell J Econ, 8(1), 23-40. https://doi.org/10.2469/dig.v27.n1.2

Sa'diyah, L. D. J., Dimyati, M., \& Murniati, W. (2019). Pengaruh Biological Asset Intensity, Ukuran Perusahaan, dan Tingkat Internasionalisasi Terhadap Pengungkapan Aset Biologis. Progress Conference, 2(July), 291-304.

Safitri, D. A. (2015). Dampak Pengungkapan Sustainbility Report Terhadap Kinerja Keuangan Dan Pasar. Skripsi. STIESIA. Surabaya

Sakinatunnisak, S. E., \& Budiwinarto, Ki. (2020). Analisis Pengaruh Biological Assey Intensity dan Profitabilitas Terhadap Pengungkapan Aset Biologi Pada Perusahaan Agrikultur yang Terdaftar di Bursa Efek Indonesia Tahun 2018. Jurnal Ekonomi Dan Kewirausahaan, 20(2), 178-185.

Sari. (2015). "Pengaruh Ukuran Perusahaan Kualitas KAP, Dan Profitabilitas Kebangkrutan Pada Audit Delay” Jurnal Akuntansi \& Manajemen. .26, No. 2, Agustus 2015.

Sharlica Evelyn. (2017). Bagaimana Perlakuan Akuntansi Untuk Aset Biologis. Sumber jtanzilo.com/b;og/detail/681/slug/bagaimana-perlakuan-akuntansi-untuk-aset-biologis.

Silva, R. dkk. (2012). Konvergensi dengan Standar Akuntansi Internasional: Analisis Pengungkapan Aset Biologis IAS 41. University of Porto.

Spance, A.M. (1973). Job Marketing Signalling. Quarterly Journal Of Economics Vol. 87, No 3. $355-374$

Sugiyono. (2017). Metode PenelitianKuantitatif, Kualitatif, dan R\&D. Bandung: Alfabeta, CV.

Suwardjono. (2014). Teori Akuntansi Perekayasaan Pelaporan Keuangan, Edisi Ketiga Cetakan Kedelapan. 
Gustria, U. \& Sabrina N. (2020). Pengaruh Profitabilitas, Ukuran Perusahaan dan Jenis KAP terhadap Pengungkapan Aset Biologis. Jurnal Eksplorasi Akuntansi. 2(1) 2362-2372. http://jea.ppj.unp.ac.id/index.php/jea/issue/view/2

Yeni Alfiana. (2018). Pengaruh Profitabilitas, Leverage, Proporsi Dewan Komisaris, Ukuran KAP dan Ukuran Perusahaan Terhadap Luas Pengungkapan Informasi Sukarela Laporan Keuangan Tahunan Perusahaan Sektor Keuangan Yang Terdaftar di Bursa Efek Indonesia. Jurnal Manajemen dan Bisnis Sriwijaya. 16 (1), 2018.

Zufriya, C., Putri, N. K., Farida, Y. N. (2020). Pengaruh Biological Asset Intensity , Konsentrasi Kepemilikan Dan Profitabilitas terhadap Pengungkapan Aset Biologis. 4(2), 271-282. Jurnal Akuntansi Syariah 4(2) 271-282. https://doi.org/10.46367/jas.v4i2.252 